\title{
Impact of Technological Diagram on Biochemical and Microbiological Quality of Borassus akeassii Wine Produced Traditionally in Burkina Faso
}

\author{
François TAPSOBA ${ }^{1, *}$, Aly SAVADOGO ${ }^{1,2}$, Cheikna ZONGO ${ }^{3}$, Alfred Sababenedyo TRAORÉ ${ }^{1,2,3}$ \\ ${ }^{1}$ Laboratory of Microbiology and Biotechnology, Research Center in Biological, Food and Nutrition Sciences (CRSBAN), Department \\ of Biochemistry and Microbiology, University of Ouagadougou, Burkina Faso \\ ${ }^{2}$ Laboratory of Food Technology, Department of Biochemistry and Microbiology, University of Ouagadougou, Burkina Faso \\ ${ }^{3}$ Laboratory of Clinical Biochemistry and pharmacology, Department of Biochemistry and Microbiology, University of Ouagadougou, \\ Burkina Faso \\ *Corresponding author: tapsobaf@gmail.com
}

Received September 20, 2014; Revised October 28, 2014; Accepted November 10, 2014

\begin{abstract}
Palm wines are produced following several traditional processes, very consumed and appreciated in West Africa. In South-West of Burkina Faso, Borassus akeassii palm wine, plays a nutritional and socio-economic role and replaces Sorghum beer. Because of reported health issues due to the bad practices of palm wine tappers, we performed survey aimed to assess the impact of technological diagrams on the quality of this wine in order to improve its quality. In South-West of Burkina Faso, survey was undertaken among tappers, vendors and consumers of palm wine, followed by microbiological and biochemical analysis. Questioning of 88 tappers, 80 vendors and 155 consumers by using cards of survey, revealed that 3 critical points were very important for improvement of wine quality. It is washing of flask used for collection with, filtration without dilution of palm wine and washing of conditioning containers. According their practices, tappers were divided into two sub-groups: Sub-groups 1 and 2. Biochemical analysis of palm wines revealed differences between the two sub-groups' processes for acidity $0.64 \pm 0.08$ versus $0.82 \pm 0.29 \%(\mathrm{~m} / \mathrm{v}), \mathrm{pH} 4.90 \pm 0.10$ versus $4.05 \pm 0.61$ and alcohol content $5.80 \pm 2.13$ versus $4.7 \pm 1.47 \%(\mathrm{v} / \mathrm{v})$ for sub-groups1 and 2 respectively. Microbiological investigations show that total and thermotolerant coliforms and Staphylococcus aureus were also detected in wine of sub-group 2 and were $5.46 \pm 1.34$, $3.15 \pm 1.90$ and $6.40 \pm 1.23 \mathrm{log} \mathrm{cfu} / \mathrm{ml}$ respectively but not detected in sub-group 1 wine. Our study shows that wine quality could be significantly improved by using undiluted sap and controlling the three critical points of main diagram.
\end{abstract}

Keywords: Borassus akeassii, palm wine, survey, technological diagrams, microbiological and biochemical quality

Cite This Article: François TAPSOBA, Aly SAVADOGO, Cheikna ZONGO, and Alfred Sababenedyo TRAORÉ, "Impact of Technological Diagram on Biochemical and Microbiological Quality of Borassus akeassii Wine Produced Traditionally in Burkina Faso.” American Journal of Food Science and Technology, vol. 2, no. 6 (2014): 179-186. doi: 10.12691/ajfst-2-6-2.

\section{Introduction}

In West Africa, more than 10 million persons consume palm wine as a beverage [18] and this beverage is also widespread in African, American and Asian tropical regions. Palm wine is an alcoholic beverage obtained from spontaneous fermentation of the sap of various species of palm tree such as palmyra and coconut palm [2]. Largely widespread in tropical regions, palm wine is known under different names in different countries including toddy in India, emu in Nigeria, lambanog in the Phillipines [20] and taberna in Mexico [27]. In Tunisia, palm sap is directly consumed as a fresh juice called legmi or used as an alcoholic beverage after spontaneous fermentation [6]. In Burkina Faso, palm wine largely produced from
Borassus akeassii sap is called bandji. This wine is colorless and very sugary [21] and it is supposed to be good for the health, eyesight and also serves as a sedative. This natural product has several nutritional and medical uses, which have been reported by many authors and it has a special place in traditional celebrations and ceremonies such as marriages, burials and settling disputes. Technics for tapping palm trees are numerous and can drastically vary from one continent to another [7]. According Santiago-Urbina and Ruíz-Terán [26], the methods of tapping palm trees depend on the locality but in general, two methods are practiced. In the first method, the sap is obtained from a live standing tree and the second; the tree is felled or cut down before tapping. In African, both methods are also used [23]. Some palm trees are felled and tapped, the quality of wine obtained from them is not considered as well as those from standing trees. In parts of 
tropical Africa and Madagascar, the palm Elaeis guineensis is destructively harvested for sap [4,11].

Major constituents of palm wine are carbohydrates, organic acids, proteins, vitamin $\mathrm{C}$ and ash [22]. Palm wine contains very little reducing sugars such as glucose, fructose, maltose and raffinose [28], and however contains various yeasts and bacteria.

Palm wine is produced traditionally by spontaneous fermentation of Borassus akeassii sap. Variable technological diagrams are used in this traditional process by the tappers, and as palm sap is not collected under aseptic conditions, the by-product may contain undesirable microorganisms harmful for the health of the consumers. In order to detect how technical diagrams may be the causes of reported health issues (intestinal discomfort, cephalgias etc...), we have undertaken a surveyamong palm wine tappers, vendors and consumers. These investigations were conducted in Sitiena and Tiekouna, two villages of Banfora, between October 2013 and February 2014. Banfora is a city, located in SouthWest of Burkina Faso (13\%38' latitude $W$ and $4^{\circ} 46^{\prime}$ ' longitude $\mathrm{N}$ ) on the national road N7, $85 \mathrm{~km}$ from BoboDioulasso and about $450 \mathrm{~km}$ from Ouagadougou where Borassus akeassii wine is highly produced and very consumed. In a second step, we evaluated the biochemical and microbiological quality of wines produced by different groups of tappers. This enables us to propose an optimal technological diagram for the improvement of palm wine quality.

\section{Material and Methods}

Three types of questionnaires were respectively used for palm wine tappers, vendors and consumers.

\subsection{Investigations on Palm Wine Tappers}

This part of the survey was undertaken to know production diagrams used and knowledge of Good Hygiene Practices by tappers. Investigations were conducted on the steps and the conditions of tapping in order to develop the main flowchart of Borassus akeassii wine traditional process. Observations were made during the tapping of sap. Knowledge of Good Hygiene Practices of tappers was evaluated using cards of investigation. Then, the actions during the tapping were watched discreetly, the cleanliness of the materials used during the tapping. A sample was taken from each palm wine tapper questioned for microbiological and biochemical analysis.

\subsection{Investigations on Palm Wine Vendors}

The investigations were carried out in 80 points of sales in South-West of Burkina Faso where we met vendors of the palm wine from the two villages in order to assess the socio-economic impact of this activity.

\subsection{Investigations on Consumers of Palm Wine}

The investigations were carried out in 20 points of sale and caterigorized as follows: 15 sites with 8 consumers surveyed per site (120 consumers) and the others 5 with 7 consumers in each site (35 consumers). A total of 155 consumers were questioned in order to know their appreciation of palm wine produced and largely consumed.

\subsection{Biochemical and Microbiological Analysis of Borassus Akeassii Palm Wine}

\subsubsection{Sampling of Borassus akeassii Palm Wine}

Palm wine samples were collected from each palm wine tapper questioned in sterile bottles (500 ml), maintained at $4^{\circ} \mathrm{C}$ in an isothermal box and immediately assigned to the laboratory for microbiological and biochemical analysis.

\subsection{Biochemical Snalysis}

Biochemical analysis carried out on the Borassus akeassii wine samples includes the $\mathrm{pH}$, the total titrable acidity and the alcohol content. The alcohol content was determined by titration using method of Perry and Don [25]. Total titrable acidity and $\mathrm{pH}$ was determined methods used by Amoa-Awua et al. [4]. Total titrable acidity was expressed as percentage of lactic acid.

\subsection{Microbiological Analysis}

Several global microbial counts such as: total viable counts, total yeasts population, total lactic acid bacteria, and specific counts for Staphylococcus aureus and coliforms (total and thermo-tolerant coliforms) were performed in order to assess the impact of the diagram on the microbial quality of palm wines.

A total of 88 Samples of freshly tapped palm wine were aseptically collected near the surveyed palm wine tappers, maintained at $4^{\circ} \mathrm{C}$ in an isothermal box at laboratory and immediately analyzed. Ten fold dilutions of each palm wine sample were achieved using $0.1 \%$ sterile peptone water (Biomerieux, France). $100 \mu \mathrm{l}$ of the appropriate diluted samples were pour plated in triplicate plates on Plate Count Agar (PCA) (Biokar, France) for total viable counts, Sabouraud with chloramphenicol Agar (Biokar, France) for yeasts counts, Man Rogosa Sharpe (MRS) (Sigma Aldrich, USA) for lactic acid bacteria counts, Chapman's Agar medium (Sigma Aldrich, USA) for Staphylococcus aureus counts, Violet Red Bile Agar (VRBL) (Biokar, France) for coliforms bacteria counts. All plates were incubated for 48 hrs at $37 \pm 2^{\circ} \mathrm{C}$ except VRBL plates that were incubated at $30 \pm 2^{\circ} \mathrm{C}$ for total coliforms and $44 \pm 2^{\circ} \mathrm{C}$ for thermo-tolerant coliforms for 48 $\mathrm{h}$ and Sabouraud with chloramphenicol plates that were incubated for $72 \mathrm{~h}$ at $30^{\circ} \mathrm{C}$. All experiments were performed in triplicate. Counts were expressed as colony forming units (cfu) per $\mathrm{ml}$ and converted to $\log 10 \mathrm{cfu} / \mathrm{ml}$.

\subsection{Data Analysis}

Data were entered into Excel 2003 and statistical analysis was performed by SPSS 17.0 software. Descriptive statistics were used to analyse survey data. One-way analysis of variance (ANOVA) were used to determine whether there are any significant differences between the means of different parameters at significance at $\mathrm{P}<0.05$.

\section{Results and Discussion}


3.1. Survey on Palm Wine Tapper, Vendors and Consumers

In Banfora, 88 palm wine tappers were surveyed in the two villages with 44 per village. They are $100 \%$ male and majority (90.9\%) of them is illiterate. Survey conducted among the palm wine tappers led to 2 technological diagrams of Borassus akeassii palm wine tapping presented in Figure 1.

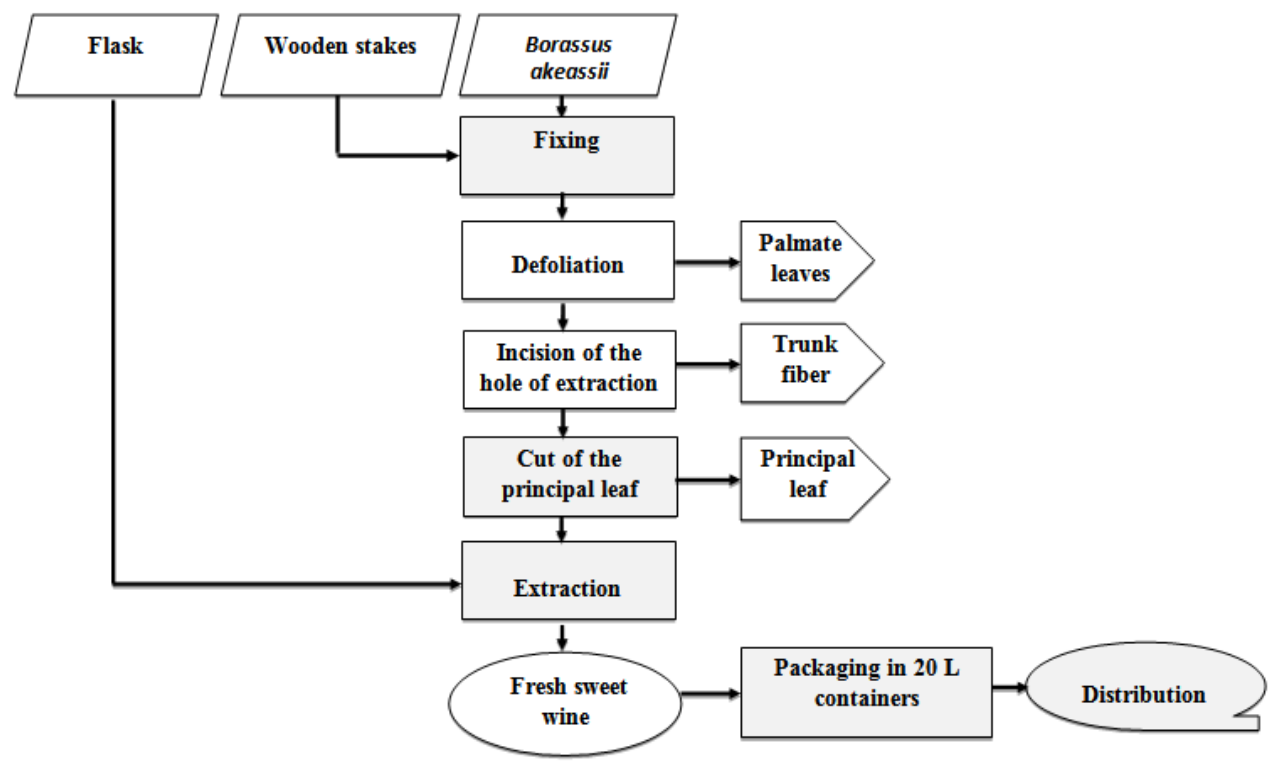

a. Palm wine tappers do not filter collected palm sap

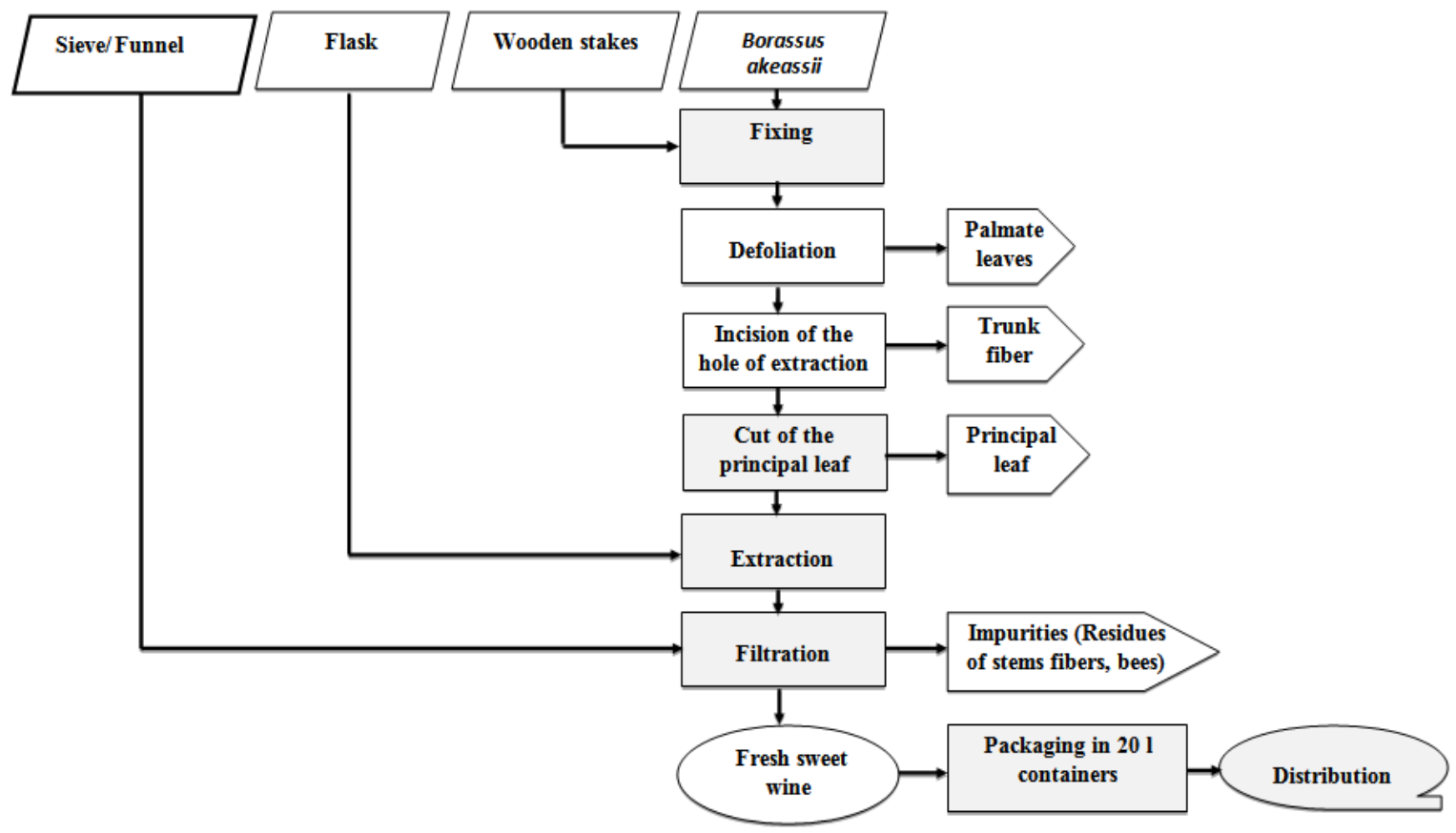

b. Palm wine tappers do not wash flask and containers used to collected palm sap

Figure 1. Different technological diagrams of Borassus akeassii palm wine tapping in Burkina Faso

From these diagrams used by palm wine tappers, we proposed an optimal one to improve the quality of palm wine as presented in Figure 2. The steps of this technological diagram are described as follow:

\subsection{Fixing of Wooden Stakes or Scale}

Wooden pegs were fixed throughout the palmyra trunk for easy access to the top of the palm tree. Some tappers use scale.

\subsection{Defoliation}

The palmate leaves were removed from palmyra except the main leaf and some leaves at the top of this tree.

\subsection{Incision of Extraction Hole}

After one week on average, the apical portion at the base of the main leaf was incised to remove the extraction hole.

\subsection{Removing of the Main Leaf}

After 2 or 3 days, the main leaf at the top of the palmyra was removed. This leaf is connected to the main vein in the center of the trunk. 


\subsection{Installation of the Flask}

After 3 days, the extraction flask was placed at the extraction hole for 6-8-hours time. After this time, the sap is collected and the emptied gourde is returned to continue the extraction. The flask is emptied twice a day.

\subsection{Filtration}

The freshly collected sap was free of impurities (residues, bees) by filtration using a sieve. The fresh sap was subjected to spontaneous fermentation.

\subsection{Conditioning and Distribution}

Fermenting fresh wine is packaged in 20 liters containers where spontaneous fermentation continues. The packed containers of palm wine are delivered to the vendors which sell it to the consumers.

Fermentation of sap begins immediately after collection and within two hours, the alcohol content reaches approximately $4 \%$ [33].

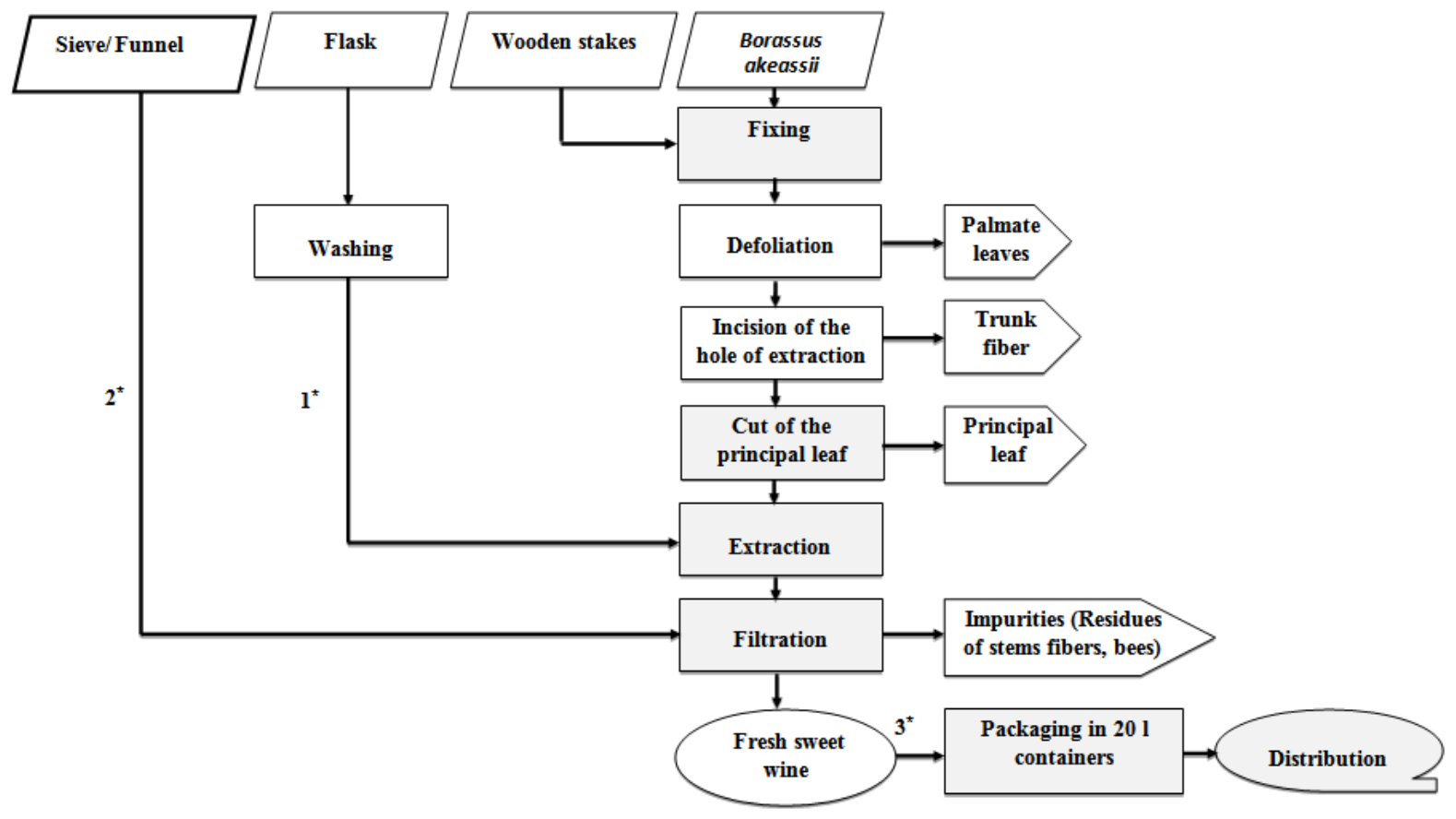

Figure 2. Main flowchart of Borassus akeassii wine traditional process in Burkina Faso

*: Critical points 1: Washing of the flask with detergent; 2: Filtration without dilution; 3: Washing of conditioning containers with detergent

In Burkina Faso, the palm wine tappers that we questioned reported that they use non-destructive method. During this procedure, palm is left standing. Our results are agreement with Ouoba et al. [24] who reported that production of palm wine by felling the tree before tapping is not practiced in Burkina Faso but is done in Ghana [4] and in Mexico [26]. According to Francisco-Ortega and Zona [11], non-destructive exploitation, can provide a sustainable harvest for the life of the palm. A palm tapped in this way survives and can be tapped again. It was reported that palm wine tapping is $100 \%$ male profession because it is a high-risk activity.

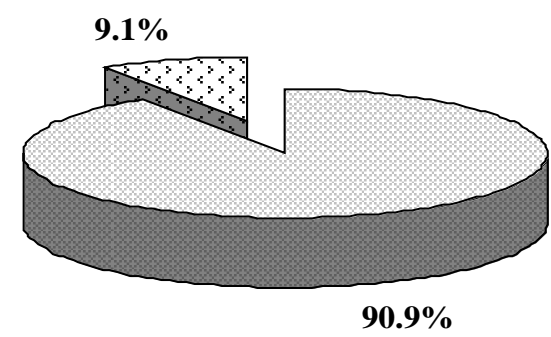

$\square$ Illeterate $\square$ Primary school

Figure 3. Educational level of palm vine tappers
Wine tappers age ranged between 20 and 43 years. It is an activity of the young population. $95.5 \%$ of the tappers practice the extraction of the palm sap throughout the year and $4.5 \%$, during the dry season. The extraction is practiced throughout the year but intense in cold period (December to February) [34]. Quantity of palm sap daily extracted ranged between 0.5 liter and 10 liters/palm tree. Majority (90.90\%) of the actors make harvest 2 times a day (morning afternoon) whereas $9.10 \%$ do it one time a day. They were $90.9 \%$ illiterate and $9.1 \%$ are primary education level as presented in Figure 3

Inquired vendors are $100 \%$ female with age ranged between 19 and 77 years. The quantity of palm wine sold by vendors daily ranged between 20 to 200 liters. The majority of the saleswomen (95\%) reported that they do not dilute the palm wine whereas a minority (5\%) reported that they dilute the palm wine. The palm wine is mainly diluted by tappers. Surveyed vendors are $100 \%$ female and according to Mbuagbaw and Noorduyn [18] and Ubokudom and Okorjin [32] women are mostly involved in sale and distribution of palm wine.

Palm wine consumed by many people, plays a socioeconomic role. This natural product an important role in people's lives because it is an important source of income. In fact, investigations results shown that a large quantity of palm wine were sold by vendors. Anywhere in the 
world, this natural product has several nutritional, medical, religious and social uses which have been reported. It has a special place in traditional celebrations and ceremonies such as marriages, burials and settling disputes. Palm wine production is providing employment to the population and replaces Sorghum bicolor beer in Burkina Faso Southwestern. Indeed, palm wine is sold from 75 (0.11 Euros/0.16 USD) to 200 (0.30 Euro/0.42 USD) CFA/liter. The daily income of palm wine selling is ranged between 2000 (3.05 Euros/125.13 USD) and 20000 (30.49 Euros/41.71 USD) Francs FCA. The monthly income was estimated approximately between $\quad \begin{array}{llll}60 & 000 & (91.49\end{array}$ Euros/41.71 USD) and 600000 (914.7 Euros/1251.3 USD) Francs CFA.

The educational level of palm wine vendors presented in Figure 4 shows that $61.5 \%$ of them are illiterate, $7.7 \%$ are primary school level and $30.8 \%$ secondary school level.

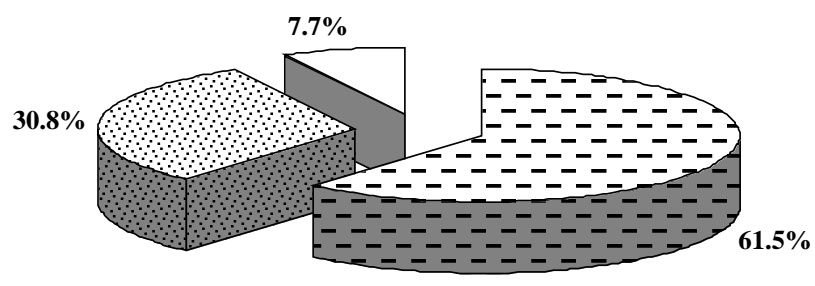

$\square$ illiterate $\square$ Secondary school $\square$ Primary school

Figure 4. Educational level of palm wine vendors

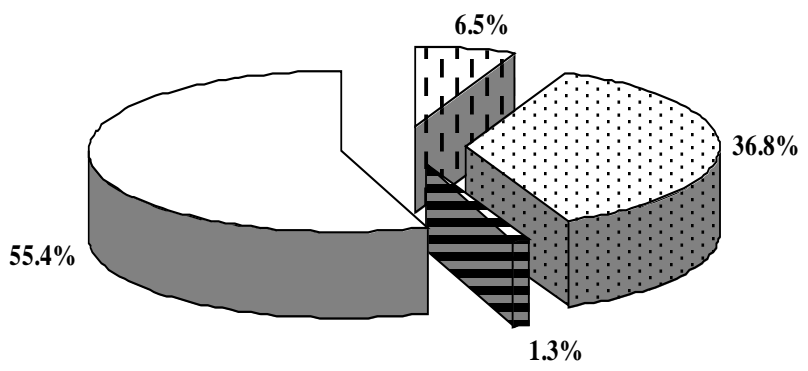

$\square$ Higher study $\square$ Illeterate $\square$ Primary School $\square$ Secondary School

Figure 5. Educational level of palm wine consumers

A third questionnaire was submitted to palm wine consumers. A total of 155 consumers of palm wine were questioned in 20 points of sale. Figure 5 shows educational level of surveyed palm wine consumers. The consumers (155) of palm wine are majority male (71.6\%) and $28.4 \%$ female. They are $36.8 \%$ illiterate, $1.3 \%$ primary school 55.4\% secondary school and 6.5\% high school with age ranged between 14 and 80 years. This shows that people of all educational levels in Banfora drink palm wine.

As shown in Figure 6, majority (64.5\%) of questioned consumers drink palm wine more than 1 time per day. They can be considered as regular consumers. Those considered as irregular consumers (35.5\%) assert to drink palm wine 2 or 3 times per week. The quantity of palm wine consumed was ranged between 0.5 and 10 liters per day. These results show the importance of this wine in the study area.

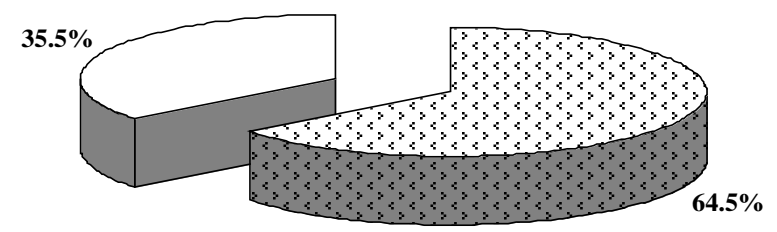

$\checkmark$ Regular consumers $\square$ Irregular consumers

Figure 6. Frequency of consumption of palm wine

Legend: Regular consumers (more than 1 time per day); irregular consumers ( 2 or 3 times per week)

Appreciation of palm wine by consumers is shown in Figure 7.

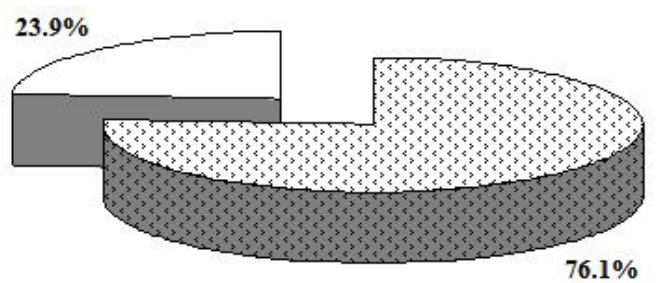

\section{GUndesirable $\square$ Good}

Figure 7. Appreciation of the palm wine produced traditionally by the surveyed consumers

Majority of consumers (76.1\%) did not appreciate the quality of wine they consume due to the bad practices of tappers and the reasons of undesirable wine is presented in Table $1.40 \%$ of the consumers made case of the acidic nature of the palm wine corresponding to 62 consumers having met undesirable palm wine at consumption, $23.2 \%$ bitter taste, $5.8 \%$ distension, $3.2 \%$ cephalgias, $2.6 \%$ insipid and $1.3 \%$ after-taste.

Table 1. Reasons of undesirable wine about consumers

\begin{tabular}{|c|c|c|c|c|c|c|}
\hline \multirow{2}{*}{ Appreciation of taste (Feeling) } & \multicolumn{2}{|c|}{ Class size } & \multicolumn{2}{|c|}{ Percentage } & \multicolumn{2}{|c|}{ Total } \\
\hline & Sub-group 1 & Sub-group 2 & Sub-group 1 & Sub-group 2 & Class size & Percentage \\
\hline Acid/ sour taste & 12.0 & 50.0 & 24.0 & 47.6 & 62.0 & 40.0 \\
\hline After-taste & 0.0 & 2.0 & 0.0 & 1.9 & 2.0 & 1.3 \\
\hline Cephalgias & 0.0 & 5.0 & 0.0 & 4.8 & 5.0 & 3.2 \\
\hline Distension/diarrhoea & 0.0 & 9.0 & 0.0 & 8.6 & 9.0 & 5.8 \\
\hline Insipid & 1.0 & 3.0 & 2.0 & 2.9 & 4.0 & 2.6 \\
\hline Good & 32.0 & 5.0 & 64.0 & 4.8 & 37.0 & 23.9 \\
\hline Total & 50.0 & 105.0 & 100.0 & 100.0 & 155.0 & 100.0 \\
\hline
\end{tabular}




\subsection{Biochemical Characteristics of Palm Wine}

Biochemical parameters of palm wine tapped by two sub-groups of tappers are presented in Table 2. Alcohol content is higher in sub-group 1 palm wine and could be due to the dilution of the beverage by tappers of sub-group 2. It was reported that the alcohol percentage ranged from 2 to $8 \%$ in Palmyra wine [1]. Spontaneous fermentation is ensured by yeasts and bacteria that convert the sweet substrate into several metabolites mainly ethanol, lactic acid and acetic acid [4,24,27,29].

Results presented in Table 2 show that $\mathrm{pH}$ average is respectively around $4.90 \pm 0.10$ and $4.05 \pm 1.61$ for subgroup 1 and subgroup 2. Total titrable acidity is respectively around $0.64 \pm 0.08 \%(\mathrm{~m} / \mathrm{v})$ and $0.82 \pm 0.29 \%$ $(\mathrm{m} / \mathrm{v})$ and the alcohol content is respectively $5.80 \pm 2.13 \%$ (v/v) and $4.7 \pm 0.68 \%$ (v/v) for sub-group 1 and sub-group 2.

Table 2. Biochemical parameters of palm wine tapped by two subgroups of tappers

\begin{tabular}{l|c|c}
\hline \multirow{2}{*}{ PARAMETERS } & Sub-groups of palm wine tappers \\
\cline { 2 - 3 } $\mathrm{pH}$ & $\mathbf{1}$ & $\mathbf{2}$ \\
Total titrable acidity (\%) & $4.90 \pm 0.10^{\mathrm{a}}$ & $4.05 \pm 0.61^{\mathrm{b}}$ \\
Alcohol (\%) & $0.64 \pm 0.08^{\mathrm{a}}$ & $0.82 \pm 0.29^{\mathrm{a}}$ \\
\multicolumn{2}{c}{$5.80 \pm 2.13^{\mathrm{a}}$} & $4.70 \pm 1.47^{\mathrm{b}}$ \\
\hline The values with different superscripts in a line are significantly different \\
$(\mathrm{p}<0.05)$
\end{tabular}

\subsection{Microbial Characteristics of Palm Wine}

The impact of critical points of main diagram is very significant at the level of microbiological analysis. Figure 8 shows the comparison of microbial quality of palm wine produced by the two sub-groups of tappers.

Total viable counts, total yeast counts, total coliforms, thermo-tolerant coliforms and Staphylococcus aureus counts are higher in palm wine of sub-group 2 than those of sub-group 1. The presence of Staphylococcus spp. and coliforms in palm wine has been reported $[17,30]$. Total coliforms, thermo-tolerant coliforms and Staphylococcus aureus counts were also detected in palm wine tapped by sub-group 2. The quality of palm wines produced by subgroup 2 are considered unsatisfactory for Total coliforms, thermo-tolerant coliforms and Staphylococcus aureus counts according to the French Association of Normalization (AFNOR) guidelines [3].

Microbial counts of palm wine tapped by sub-group 1 are lower than those of sub-group 2 excepted Lactic acid bacteria (LAB) counts. There is no difference between LAB counts $(\mathrm{P}<0.05)$. LAB counts shown that palm wine lodges a high number of these microorganisms (Figure 8). They ranged respectively between $6.07 \pm 1.30 \mathrm{log} \mathrm{cfu} / \mathrm{ml}$ and 5.57 $\pm 2.83 \log \mathrm{cfu} / \mathrm{ml}$ for sub-group 1 and sub-group 2 . The presence of these organisms are not surprising as most of them are known to thrive in medium rich in fermentable substrates such as sugars which often led to the production of acids after fermentation [8]. The microflore of the palm trees directly contaminates the sap on the hole carried out by the tapper and thus constitutes the principal source of micro-organisms of the sap. However, the micro-organisms could come from the water used during the extraction, either to wash the container having been used for the collection of the sap or to dilute the sap in order to increase their income [22]. The high population of yeast may be due to the fact that the fermentation is not controlled, and the yeast inoculums comes mainly from unsterilized containers, previously used for the collection of sap. Educational level is very important for knowledge of Good Hygiene Practices. In fact, the results of our investigations show that the majority of the tappers are illiterate and also ignore Good Hygiene Practices. Consequences are the presence of coliforms in wine. Palm wine is an excellent substrate for microbial growth and is not subjected to any form of sterilization such as pasteurization or heating [8]. It is therefore, essential that proper hygienic collection procedures are followed to prevent contaminating bacteria from competing with the yeast and producing acid instead of alcohol. It was reported that the methods of palm wine tapping and collection of palm sap influence the microbial content of the sap [5].

Following the investigations and the observations carried out near the tappers, differences were noted on the level of points 1,2 and 3 on the main technological diagram in Figure 2. It is respectively about Hygiene of flask (1), Filtration without dilution of palm wine (2) and washing of conditioning containers with detergent (3) which are important critical points and could affect significantly palm wine quality. Palm wine tappers were subdivided in 2 sub-groups: Sub-group 1 and sub-group 2 . Tappers of Sub-group 2 do not respect the critical points because they do not filter the collected sap and use unwashed flask and containers for harvest. They also use palm wine or untreated water to wash their materials and dilute the palm sap freshly collected in order to increase their incomes. These practices constitute an important source of microbial contamination. On the other hand, tappers of sub-group 1 respect the critical points. In fact, they wash the materials with detergent and do not dilute the palm sap.

Only $18.2 \%$ of the tappers do not dilute the palm sap after harvest while majority (81.8\%) dilutes it in order to increase their income. The dilution rate of palm wine ranged between 10 and $60 \%$ (water/palm wine). According to Olawale et al. [22], palm wine is made traditionally and usually diluted with untreated water available in most rural communities. As reported by Mbuagbaw and Noorduyn [18], palm wine may be contaminated by artificial sweeteners, bacteria, dirty containers or unfiltered water used to increase its quantity, leading to outbreaks of diarrheal diseases. Majority (70.45\%) of the tappers does not use a detergent to wash their flasks and containers used for harvest and $29.55 \%$ of tappers use unwashed material.

Maximum duration of fermentation ranged between 2 hours and 96 hours and the maximum duration of conservation between 1 and 7 days. Majority (72.7\%) reported that the maximum duration of conservation is less than or equal to 4 days. After these periods, palm wine is inconsumable. Indeed, beyond 96 hours of fermentation, palm wine is acidified and gets inconsumable [30].

During spontaneous fermentation, the microflore fermentates sugars of the crude sap of Borassus akeassii into alcohol and then into various organic compounds responsible for the bad quality of the wine depreciated by 
the consumers [1]. The sour taste and short shelf life could be attributed to the large number of microbial flora, particularly the lactic acid bacteria present in palm wine [12] that produce undesirable metabolites. Palm wine $\mathrm{pH}$ is respectively around $4.90 \pm 0.10$ and $4.05 \pm 0.61$ for subgroup 1 and sub-group 2, thus explaining the acid taste revealed by the consumers in our investigation. It was reported that $\mathrm{pH}$ average of palm wine was $4.08 \pm 0.19$ [31] and decreases to $3.21 \pm 0.16$ at the fifth day days of spontaneous fermentation at room temperature and $\mathrm{pH}$ depends on the stage of fermentation at which the wine is consumed [15]. The acidic nature of these products is due to the production of organic acids during the process of fermentation by acid producing microorganisms as the fermentation is carried out under unhygienic and uncontrolled conditions [14].

Figure 7 shows that consumption of palm wine produced traditionally can present risks for the health of consumers. In fact, majority (76.1\%) of consumers having met undesirable wines with consumption gave diversified reasons mentioned in Table 2.

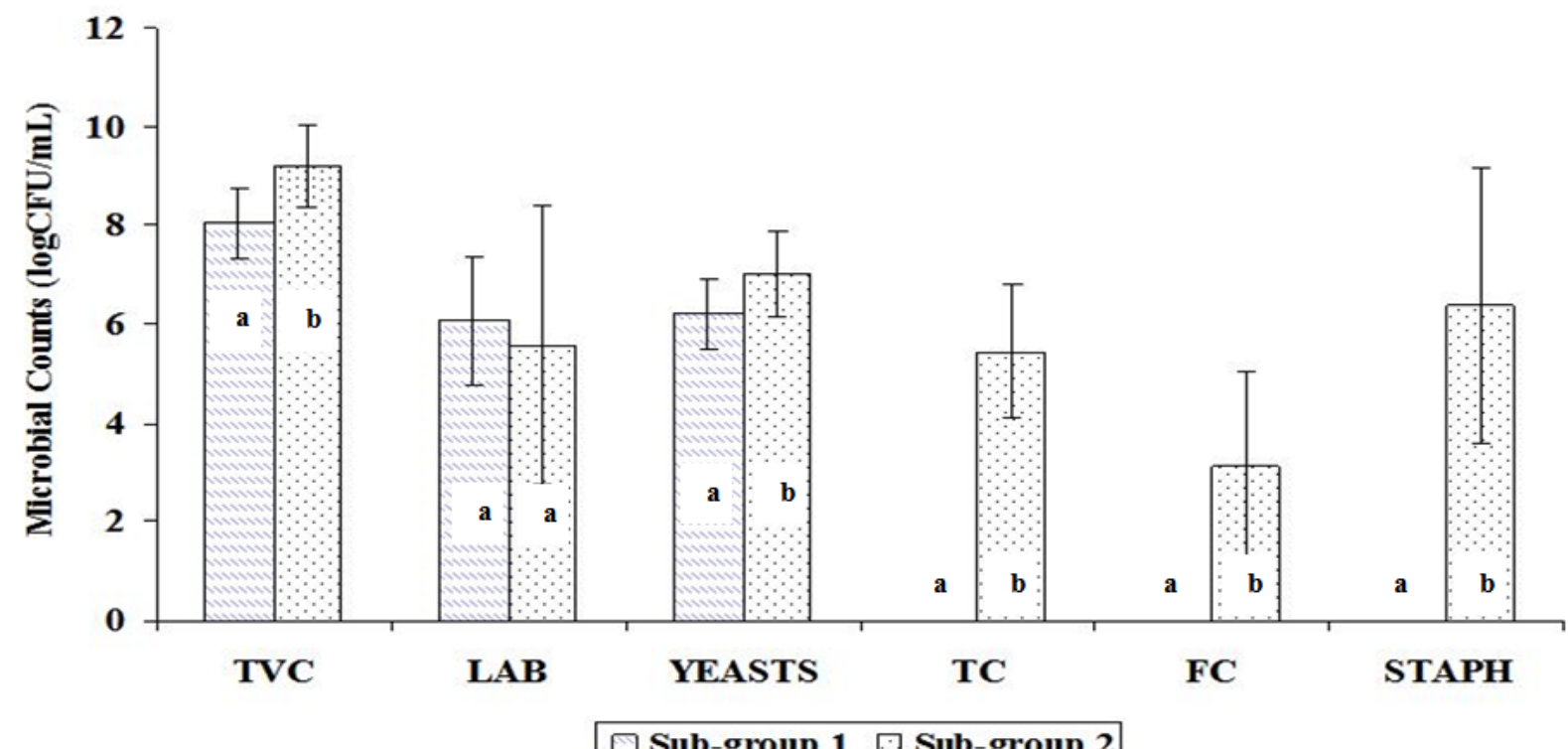

Figure 8. Impact of technological diagram on microbial quality of Borassus akeassii palm wine

The values with different letters (a, b) on the same group indicate significant difference at $\mathrm{P}<0.05$

Legend: TVC: Total Viable Counts; LAB: Lactic Acid Bacteria; TC: Total coliforms, FC: Thermo-tolerant Coliforms; STAPH: Staphylococcus aureus

The presence of coliforms bacteria and Staphylococcus aureus in palm wine points out the lack of hygiene during the tapping and conditioning of the palm wines by subgroup 2. The presence of Staphylococcus species was possible contaminants from handlers. Staphylococcus aureus, a mesophile have been implicated in food poisoning outbreak of some food material [8]. Majority (90.90\%) of palm wine tappers are illiterate, a situation already described in Nigeria [32].

The organisms of palm wine have also been reported to originate from several sources, including tapping equipment, containers and the environment [9]. Organisms such as coliforms and various species of the Staphylococcus genus are particularly associated with food-borne illnesses relating to poor sanitation and improper food handling [16]. The distensions met by consumers are due to the producing gas microorganisms. Thus, water is an important input in palm wine preservation although this is often denied or even masked by addition of artificial sweeteners. Indeed, one of the most frequent complaints of palm wine consumers is the adulteration of the product by use of water and artificial sweeteners, which sometimes result in diarrhoea, abdominal pains and stomach problems [13]. Palm wine cannot be preserved for more than one day; the sap becomes very sour which makes the product unacceptable by the consumers [19].

\section{Conclusion}

Palm wine is produced in Burkina Faso using no destructive method according to the main technological diagram. Our results show that the lack of hygiene during the palm wine tapping leads to palm wine, depreciated by consumers. Palm wine tappers through their practices can contribute significantly to improve palm wine quality. Health education training should be organized regularly for the tappers by the health workers on the importance of cleanness of their environment and the conditioning materials. A controlled fermentation using starters may be necessary for improvement of palm wine quality and make it competitive against other local beverages.

\section{Acknowledgement}

This work was supported by International Foundation for Science (IFS) and West African Economic and Monetary Union (UEMOA). The authors are grateful to IFS, WAEMU and palm wine tappers, vendors and consumers at Banfora.

We would like to thank Dr. Jean-Luc LEGRAS, INRA UMR1083 Montpellier, France for his helpful comments. 


\section{Reference}

[1] Ababio, O.Y. (1990). Organic Chemistry in: New School Chemistry. ( $1^{\text {st }}$ edn), Africana-Fep publishers Limited, 378-380.

[2] Adeleke, R.O., and Abiodun, O.A. (2010). Physico-chemical Properties of Commercial Local Beverages in Osun State, Nigeria. Pakistan Journal of Nutrition, 9, 853-855.

[3] AFNOR (Association Française de Normalisation), (2009). "Normes Agroalimentaires" http://www.afnor.org/secteurs/activite/agroalimentaire/normes/list e-des-norme

[4] Amoa-Awua, W.K., Sampson, E.K., and Tano-Debrah, K. (2007) Growth of yeasts, lactic and acetic bacteria in palm wine during tapping and fermentation from felled oil palm (Elaeis guineensis) in Ghana. Journal of Applied Microbiology, 102, 599-606.

[5] Ayernor, G.K.S., and Matthews, J.S. (1971). The sap of the palm Elaeis guineensis Jacq as raw material for alcoholic fermentation in Ghana. Tropical Science, 13, 71-83.

[6] Ben Thabet, I., Francis, F., De Pauw, E., Besbes, S., Attia, H., Deroanne, C., and Blecker, C. (2010). Characterization of proteins from data palm sap (Phoenix dactylifera L.) by a proteomic approach. Food Chemistry, 123, 765-770.

[7] Dalibard, C. (1999). Overall view on the tradition of tapping palm trees and prospects for animal production. Livestock Research for Rural Development, 11: 1.

[8] Essien, E., Monago, C., and Edor, E.A. (2011). Evaluation of the nutritional and microbiological quality of Kunun (A Cereal Based Non-Alcoholic Beverage) in Rivers State, Nigeria. The Internet Journal of Nutrition and Wellness, 10: 2.

[9] Faparusi, S.I., and Bassir, O. (1972a). Factors affecting palm wine. Period of tapping. West African journal of biological and applied chemistry, 15, 24: 32

[10] Fellows, P. (1997). Traditional Foods, Intermediate Technology Publications, UK.

[11] Francisco-Ortega, and J., Zona, S. (2013).Sweet Sap from Palms, a Source of Beverages, Alcohol,Vinegar, Syrup and Sugar. Vieraea, 41, 91-113.

[12] Frazier, W.C., and Westhoff, D.C. (1995). Food Microbiology. 4th ed. New Delhi: Tata McGraw-Hill publishing Company Limited. pp. 384-96.

[13] GRI. (2004). Palm wine dying a painful death. A feature by Ghana Review International.

[14] Kanvar, S.S., Gupta, M.K., Catoch, and C., Kanvar, P. (2011) Cereal based traditional alcoholic beverages of Lahaul and Spiti area of Hamachal Pradesh. Indian journal of traditional knowledge, 10 (2), 251-257.

[15] Lasekan, O., Buettner, A., and Christlbauer, M. (2007). Investigation of important odorants of palm wine (Elaeis guineensis). Food Chemistry, 105 (1), 15-23.

[16] Lawrie, R. (1998). Lawrie`s meat science (6th Edition), Woodhead Publishing Ltd Cambridge.

[17] Malonga, A., Mavoungou, O., Kobawila, S.C., and Louembe, D. (1995). Etude microbiologique et biochimique du vin de palme (Elaesis Guineensis Jacq) en République du Congo. Microbiologie, Aliments, Nutrition, 13 (2), 195-200.

[18] Mbuagbaw, L., and Noorduyn, S.G. (2012). Palm wine trade: Occupational and heal hazards. The International Journal of Occupational and Environmental Medicine, 3 (4), 154-164.
[19] Mintah, B.K., Eliason, A.E., Barimah, J., and Oldham, J.H. (2011) Development of syrup and "malt like" drink from Raphia hookeri sap. African Journal of Food, Agriculture, Nutrition and Development, 11, 5203-5219.

[20] Noll, R.G. (2008). The wines of West Africa: History, technology and tasting notes. Journal of Wine Economics, 3, 85-94.

[21] Obahiagbon, F.I., and Osagie, A.U. (2007). Sugar and macrominerals composition of sap produced by Raphia hookeri Palms. African Journal of Biotechnology, 6 (6), 744-750.

[22] Olawale, A.K., Akintobi, A.O., and David, O.M. 2010. Evaluation of microbial quality and alcoholic improvement of natural and fermented Raphia Palm wine (“Ogoro”). New York Science Journal, 3 (2), 35-39.

[23] Onuche, P., Shomkegh, S.A., and Tee, T.N. (2012). Palm wine tapping methods among idoma and tiv ethnic groups of Benue state, Nigeria: implications on conservation of palm trees (Elaeis guineensis). Journal of Environmental Issues and Agriculture in Developing Countries, 4: 1.

[24] Ouoba, L.I.I., Kando C., Parkouda, C., Sawadogo-Lingani, H., Diawara, B., and Sutherland, J.P. (2012). The microbiology of Bandji, palm wine of Borassus akeassii from Burkina Faso: identification and genotypic diversity of yeasts, lactic acid and acetic acid bacteria, Journal of Applied Microbiology, 1364-5072.

[25] Perry, R.H., Don G. (1984). Handbook of Chemical Engineering, McGraw-Hill, New York.

[26] Santiago-Urbina, J. A., and Ruíz-Terán, F. (2014). Microbiology and biochemistry of traditional palm wine produced around the world. International Food Research Journal, 21 (4), 1261-1269.

[27] Santiago-Urbina, J.A., Verdugo-Valdez, A.G., and Ruíz-Terán, F. (2013). Physicochemical and microbiological changes during tapping of palm sap to produce an alcoholic beverage called "Taberna", which is produced in the south east of Mexico. Food Control 33: 58-62.

[28] Singaravadivel, K., Alagusundaram, K., and Hariharan, B. (2012). Physicochemical properties of fresh and stored coconut palm toddy. Open Access Scientific Reports, 1: 8.

[29] Stringini, M., Comitini, F., Taccari, M., and Ciani, M. (2009). Yeast diversity during tapping and fermentation of palm wine from Cameroon. Food Microbiology, 26, 415-420.

[30] Tapsoba, F., Savadogo, A., Somda, K.M., Zongo, C., Barro, N., and Traoré, S.A. (2011). Microbial biodiversity and physicochemical parameters of some Palmyra (Borassus akeassii) wines traditionally produced in Burkina Faso, Revue de Microbiologie Industrielle, Sanitaire et Environnementale, 5 (2), 1-22

[31] Tiepma, N.E.F., Zambou, NF., Agbor, E., and Tchouanguep, M.F. (2013). Physicochemical changes of raffia sap (Raphia mambillensis) contents during spontaneous fermentation. African Journal of Biotechnology, 12 (41), 6013-6018.

[32] Ubokudom, E.O., and Okorjin, E.C. (2014). Economic analysis of Raphia palm (Raphia spp.) wine production in Akwa Ibom state, Nigeria. International Journal of Agriculture and Crop Sciences, 6 , 347-352.

[33] Ukhum, M.E., Okolie, N.P., and Oyerinde, A.O. (2005). Some mineral profiles of fresh and bottled palm wine-a comparative study. African Journal of Biotechnology, 4, 829-832.

[34] Yaméogo, J., Belem, O.M., Bayala, J., Ouédraogo, B.M., and Guinko, S. (2008). Uses and commercialization of Borassus akeassii Bayton, Ouédraogo, Guinko non-wood timber products in South-Western Burkina Faso. West Africa. Biotechnology, agronomy, society and environment, 12 (1), 47-55. 